\title{
Establishment of a planted field with Mediterranean shrubs in Sardinia and its evaluation for climate mitigation and to combat desertification in semi-arid regions
}

\author{
De Dato GD, Loperfido L, De Angelis P*, Valentini R
}

Forested areas are important in arid and semi-arid regions primarily to combat desertification, but also to increase carbon sinks. To reverse the land degradation processes, restoration in the Mediterranean Basin had been frequently obtained by planting indigenous and exotic conifers, but it has been demonstrated that shrubs are nurse species for tree seedlings. Furthermore, planting indigenous shrubs is more efficient than allochthonous in restoring degraded soils. The aims of this work were: 1) to illustrate an experimental area in Sardinia used as a test-site to build up afforestation and reforestation activities in arid and semi-arid areas with autochthonous shrub species; 2 ) to show the results on plant survival and biomass one year after plantation trying to explain the role of different densities and specific compositions; 3 ) to hypothesize some trends of C accumulation of this "artificial" Mediterranean semi-arid shrubland by comparison with data found in the literature. The area is located in North West Sardinia, and is characterized by a Mediterranean climate. The revegetation was set up in February 2006, planting local species (Juniperus phoenicea, Pistacia lentiscus and Rosmarinus officinalis). Three densities and three specific compositions (monospecific plots with $P$. lentiscus, monospecific plots with $J$. phoenicea and mixed plots with the three cited species) were combined. One month after plantation, almost all plants were alive, but mortality increased after summer, independently of the treatments, likely due to summer drought. During the first year, no differences among the densities and the specific compositions were observed. Total above-ground biomass was in the range of $0.8-3.0 \mathrm{~g} \mathrm{~m}^{-2}$. Below-ground biomass was in the range of $0.9-1.7 \mathrm{~g}$ $\mathrm{m}^{-2}$. A significant lower biomass was measured in October, especially in the Pistacia plots. Higher densities and plant mixing seemed to better perform, allowing establishment of species with a strong pioneer behaviour and aridity resistant characteristics. Data collection on initial conditions and recurrent monitorings will be basic for evaluating in the long term the potential positive effects on $C$ stock and on biodiversity of afforestation activities in arid and semi-arid areas.

Keywords: C stock, Mediterranean shrubland, Restoration

\section{Introduction}

Forested areas are important in arid and semi-arid regions primarily to combat deser-

$\triangle$ Department of Forest Environment and Resources, University of Tuscia, v. S. Camillo De Lellis snc, I-01100 Viterbo (Italy)

@ Paolo De Angelis (pda@unitus.it)

Received: Jan 08, 2009 - Accepted: Apr 02, 2009

Citation: De Dato GD, Loperfido L, De Angelis $P$, Valentini R, 2009. Establishment of a planted field with Mediterranean shrubs in Sardinia and its evaluation for climate mitigation and to combat desertification in semi-arid regions. iForest 2: 77-84 [online: 2009-06-10] URL:

http://www.sisef.it/iforest/show.php? id $=498$ tification, but also to increase carbon sinks (Lal 2001). The Mediterranean basin is particularly vulnerable to the desertification, as consequence of a mixed of environmental factors and human pressures. In the first category we can cite the occurrence of prolonged drought spells, the presence of highly erodible soils, the high flammability of the species; in the latter, the most relevant phenomena are land abandonment and urbanization of the coastal areas (Yaalon 1997, López-Bermúdez et al. 1998, Begni et al. 2001, Corona 2005). According to several studies (Costantini et al. 2004, see also http://dismed.eionet.europa.eu/index_html), Sardinia is an island with high risk of desertification. To reverse the land degradation processes, restoration in the Mediterranean Basin had been frequently obtained by plan- ting indigenous and exotic conifers (Pausas et al. 2004), because of their rapid growth and aridity resistance. In Sardinia, in particular, this type of reforestation covered more than 40,000 ha in the 70's (Bianchi et al. 2005). On one hand, these interventions provided job for local people, but on the other hand, they substantially altered the original landscape and made erosion processes start (Bianchi et al. 2005). Maestre \& Cortina (2004) wrote a comprehensive review of the ecological effects of Pinus halepensis plantations in the Mediterranean Basin. According to these authors, supported by several other studies (Maestre et al. 2003, Bellot et al. 2004, Bonet 2004, Maestre et al. 2004) classic reforestation by Pinus did not effectively facilitate the establishment of late-successional shrubs under tree canopy. Furthermore, a forest cannot be representative of later stages of succession under semi-arid conditions, because of the scarcity of water resources (Bonet 2004).

On the contrary, it has been demonstrated that shrubs are nurse species for tree seedlings, especially in the Mediterranean region (Castro et al. 2002, Martínez 2003, Castro et al. 2004b, Padilla \& Pugnaire 2006). Therefore, shrubs can protect and improve water and light regime, allowing the germination of seeds and the establishment of late-successional species. Planting shrubs improves physical and chemical soil properties, creating a favourable environment for soil microbes (Garcia et al. 2002, Pariente 2002, Goberna et al. 2007). Furthermore, the recovery of soil characteristics is the first step leading to reduction of desertification processes (Kassas 1999, Lal 2001) and increasing soil cover by plantation is a successful way to preserve soil (Pariente 2002, Sarah \& Rodeh 2004).

In the present study, we planted three species (J. phoenicea, R. officinalis, and P. lentiscus) selected among the pioneer species colonizing soil after disturbances in this area (Biondi et al. 2001). Several studies reported that planting indigenous shrubs is more efficient than allochthonous in restoring degraded soils (Olukoye et al. 2003, Caravaca et al. 2003a, Rey Benayas \& Camacho-Cruz 2004, Harris et al. 2006). In Mediterranean areas, planting indigenous species adapted to limited nutrient and water resources is essential to obtain high survival rates. But at the same time, plenty of literature (Eliason \& Allen 1997, Estaún et al. 1997, Pascual et al. 2000, Ginsberg 2002, Rey Benayas et al. 2002, Caravaca et al. 2003a, Caravaca et al. 2003b, Caravaca et al. 2003c, Clemente et al. 2004, Sarah \& Rodeh 2004, Green et al. 2005, Rey Benayas et al. 2005) indicates seedling quality, weeding, irrigation, amendants, mychorrizal inoculation, and the right 
timing of planting as other important factors. The aims of this work were: 1) to illustrate an experimental area in Sardinia used as a test-site to build up afforestation and reforestation activities in arid and semi-arid areas with autochthonous shrub species, using the minimum amount of external energy input (minimum tillage, no irrigation, etc.); 2) to show the results one year after plantation trying to explain the role of different densities and specific compositions; 3 ) to hypothesize some trends of $\mathrm{C}$ accumulation of this "artificial" Mediterranean semi-arid shrubland by comparison with data found in the literature.

\section{Materials and Methods}

\section{Experimental site and plant material}

The experimental area is located in the peninsula of Capo Caccia (north-western Sardinia), within the Natural Reserve Porto Conte Capo Caccia $\left(40^{\circ} 37^{\prime} \mathrm{N}, 8^{\circ} 10^{\prime} \mathrm{E}\right)$. The geologic substrate is Mesozoic limestone. The main natural soil type is Terra Rossa (Lithic Xerorthent and Typic Rhodoxeralfs - USDA 1993, Valsecchi 1976, Pietracaprina 1989), rocky and shallow $(20-30 \mathrm{~cm})$, with a sandy loam texture, an $\mathrm{ABC}$ profile, and neutral $\mathrm{pH}$. The experimental area (about $5 \mathrm{ha}$ ) was established in abandoned arable soil, which has been used in the past for wheat production.

The climate is semi-arid: the average rainfall amount is $640 \mathrm{~mm} \mathrm{yr}^{-1}$; precipitation falls in autumn and spring with a long dry period from May to August, with about 60 $\mathrm{mm}$. The mean annual temperature is 16.8 ${ }^{\circ} \mathrm{C}$. The mean of minimum temperatures in the coldest month is $7{ }^{\circ} \mathrm{C}$, the mean of the maximum temperatures in the hottest month is $28{ }^{\circ} \mathrm{C}$ (meteorological station of Fertilia Airport $40^{\circ} 38^{\prime} \mathrm{N} 8^{\circ} 17^{\prime} \mathrm{E}$; altitude $40 \mathrm{~m}$ asl; sea distance $4273 \mathrm{~m}$; period of observation 1961-1990).

In the Natural Reserve, four different vegetation types can be recognized: olm-oak forest, saved from the overexploitation of the XVI century (Biondi et al. 2001); an afforested area, set up in the '70s, with Pinus halepensis Mill., P. pinea L., Cupressus sempervirens L., Eucalyptus spp.; shrublands, which are widespread all over the area, particularly along the firebreak strips, the slopes and under Pinus plantations (Biondi et al. 2001); Cistus shrublands, recolonizing abandoned land and burned areas. Cultivated surfaces are now abandoned.

Planting was performed in February 2006. Autochthonous shrubs species were planted, all grown in local nurseries managed by the Regional Forest Service of the Autonomous Region of Sardinia. The species were Juniperus phoenicea L. (JP), Pistacia lentiscus L. (PL), and Rosmarinus officinalis L. (RO) Plants derived from seed and were 2-3 years old. Juniperus seedlings were transplanted
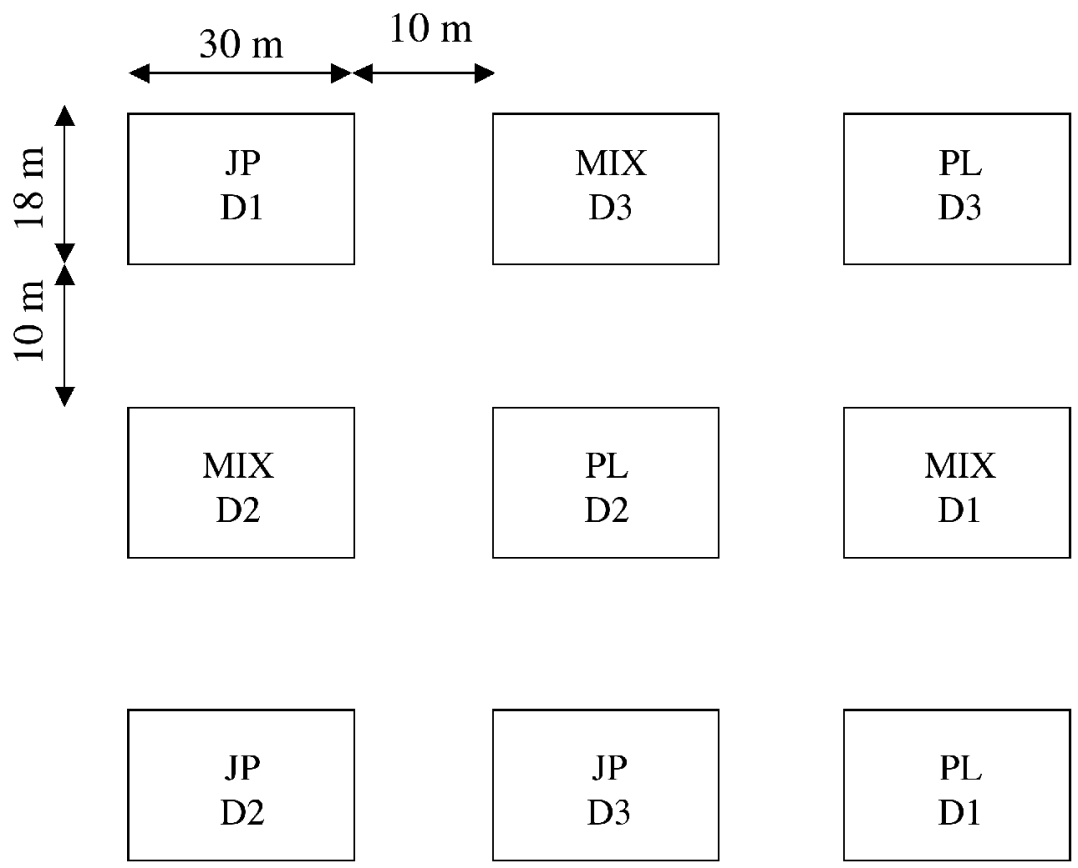

Fig. 1 - An example of a block. The drawing is not scaled.

from $30 \mathrm{~cm}$ long phytocells; Rosmarinus and Pistacia seedlings were transplanted from squared pots $(10 \times 10 \times 10 \mathrm{~cm})$. Nine plots (36 x $18 \mathrm{~m}, 10 \mathrm{~m}$ spaced), were located according to a randomized block design with 4 replicates (36 plots). In each block (Fig. 1) three different species compositions were planted at three different densities: 2000 plant ha $^{-1}$ (D1 - spaced $2 \times 2.5 \mathrm{~m}$ ), 2500 plant ha ${ }^{-1}$ (D2 - spaced $2 \times 2$ m), 3333 plant $\mathrm{ha}^{-1}$ (D3 - 2 x $1.5 \mathrm{~m}$ ). The plot specific compositions were: monospecific with JP; monospecific with PL; plurispecific plots with JP, PL and RO (MIX). Before planting, soil was superficially ploughed at $35 \mathrm{~cm}$ depth. All the area was fenced to avoid grazing.

\section{Plant survival and plant biomass estim-} ation

Plant status (alive or dead) was measured one, five and eight months after plantation, i.e., March, July and October 2006. Plants were recorded as dead when no live aboveground parts were found or when no plant

Tab. 1 - Coefficients $( \pm \mathrm{SE})$ of the allometric regressions applied for biomass estimation. AG: above-ground biomass; BG: below-ground biomass; Db: basal diameter; H: maximum height; $\mathrm{V}_{\mathrm{a}}$ apparent volume (= orthogonal maximum crown diameters $\mathrm{x}$ maximum height).

\begin{tabular}{ccccc}
\hline \multirow{2}{*}{ Parameter } & \multicolumn{2}{c}{ J. Phoenicea } & R. officinalis & P. lentiscus \\
\cline { 2 - 5 } & \multicolumn{2}{c}{$\mathbf{B}=\mathbf{a} \cdot \mathbf{e}^{\mathbf{b} \cdot \mathbf{D b}}$} & $\mathbf{B}=\mathbf{a} \cdot \mathbf{H}^{\mathbf{b}}$ & $\mathbf{B}=\mathbf{a} \cdot \mathbf{V}_{\mathbf{a}}$ \\
\cline { 2 - 5 } & $\mathbf{A G}$ & $\mathbf{B G}$ & $\mathbf{A G}$ & AG \\
\hline $\mathrm{a}$ & $3.43(1.50)$ & $0.90(0.36)$ & $0.006(0.01)$ & $577.6(17.4)$ \\
$\mathrm{b}$ & $0.23(0.05)$ & $0.31(0.05)$ & $1.981(0.68)$ & - \\
$\mathrm{n}$ & 32 & 32 & 10 & 4 \\
$\mathrm{r}^{2}$ & 0.47 & 0.64 & 0.53 & 0.99 \\
\hline
\end{tabular}

were visible.

In February-March 2006, 16 plants in the monospecific plots and 12-13 per each species in the plurispecific ones were measured for biomass estimation.

Above- and below-ground biomass estimation was based on site species-specific allometric equations, based on the following model (eqn. 1):

\section{biomass $=f($ dimensional parameter $)$}

These equations were calculated on 32 plants of Juniperus phoenicea and 10 plants of Rosmarinus officinalis, randomly selected among plantation seedlings.

For each seedling, basal diameter $\left(D_{b}\right)$, height $(\mathrm{H})$ and the two orthogonal maximum crown diameters $\left(D_{\mathrm{c} 1}\right.$ e $\left.D_{\mathrm{c} 2}\right)$ were measured. The plants were separated in stem, branches, leaves and roots, then dried at $70{ }^{\circ} \mathrm{C}$ until constant weight. The root/shoot ratio $(\mathrm{R} / \mathrm{S})$ was then calculated.

$J$. phoenicea aboveground and below- 


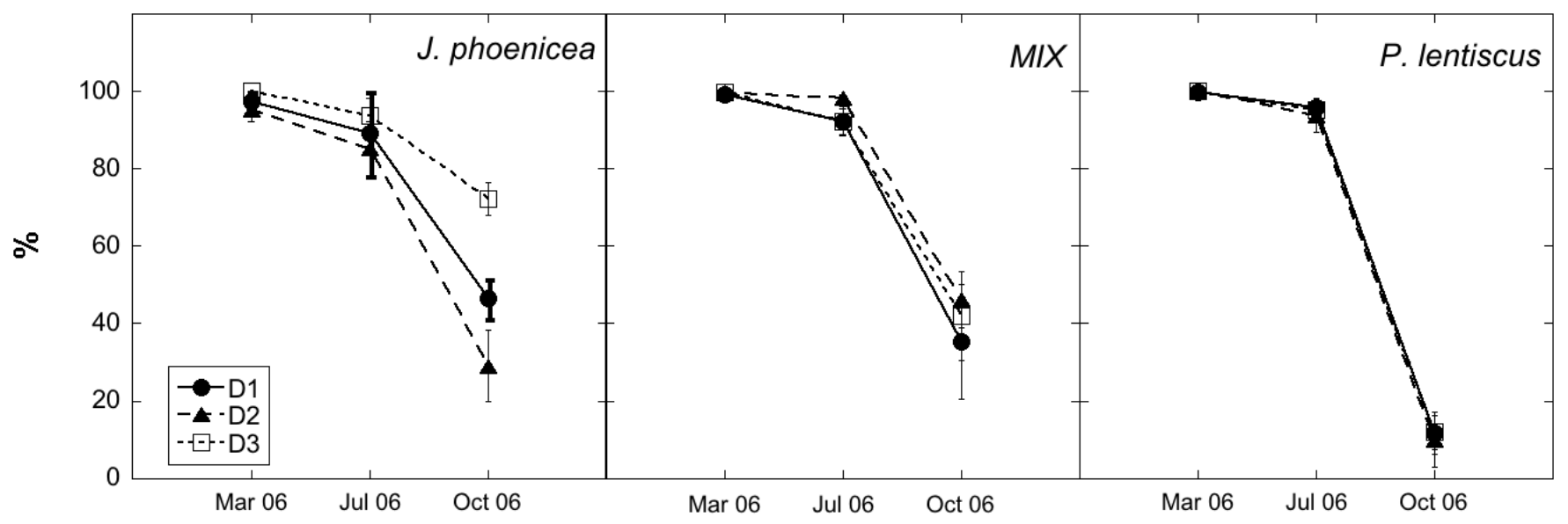

Fig. 2 - Living plant percentage in the plots according to densities and specific composition. Error bars indicate SE of the mean ( $n=4)$. For details about the statistical differences among the treatments, see Tab. 2.

Tab. 2 - Results of the ANOVA run for alive plants in the JP, PL and MIX plots.

\begin{tabular}{lccc}
\hline \multicolumn{1}{c}{ Components } & df & F & P \\
\hline specific composition & 2 & 4.77 & $<0.01$ \\
density & 2 & 1.93 & 0.15 \\
time & 2 & 287.08 & $<0.001$ \\
specific composition * density & 4 & 2.92 & $<0.05$ \\
specific composition * time & 4 & 9.96 & $<0.001$ \\
density * time & 4 & 0.57 & 0.69 \\
specific composition * density * time & 8 & 0.42 & 0.91 \\
\hline
\end{tabular}

ground biomasses were related to the basal diameter (Tab. 1). R. officinalis aboveground biomass was related to height (Tab. 1), while no relationship was found for the belowground biomass. For this reason, its belowground biomass in the field was estimated applying a fixed R/S (0.68), as found for the plants used in laboratory for the calculation of allometric regression. For Pistacia lentiscus, the allometric relation for the aboveground biomass was taken from a previous study in the same area (De Dato 2004). Belowground biomass of $P$. lentiscus was calculated applying the R/S (0.5) reported by Maestre et al. (2003) for potted plants.

\section{Soil carbon and nitrogen}

To estimate the initial values of soil total organic carbon (TOC) and nitrogen (TN), 144 soil cores (4 samples per plot) at two depths $(0-20 \mathrm{~cm}$ and $20-40 \mathrm{~cm})$ were collected just before the plantation. The samples were dried at air temperature and sieved at 2 $\mathrm{mm}$. Sub-samples of each core were then dried at $105{ }^{\circ} \mathrm{C}$ and analysed by an Elemental Analyser (Flash EA 112 - Thermo Electron, Italy), after the reaction with $\mathrm{HCl}$ to remove the inorganic carbon (Method ISO 10694).

\section{Statistical analysis}

Statistical differences $(\mathrm{p}<0.05)$ of plant sur- vival rates among the different specific compositions and densities were detected by ANOVA, with Bonferroni post-hoc test when the factor was significant. ANOVA was also run to test plant survival rates among species and densities inside the MIX plots. Prior to analysis, survival data were transformed by taking the arcsin of the square root of percentage survival.

Statistical differences $(p<0.05)$ of plant biomass among the different specific compositions and densities were analysed by ANOVA, with Bonferroni post-hoc test when the factor was significant. ANOVA was also run to test biomass differences among species and densities inside the MIX plots.

ANOVA was used to highlight statistical differences $(\mathrm{p}<0.05)$ in soil total organic carbon (TOC) and total nitrogen (TN) content at the different depths $(0-20 \mathrm{~cm}$ and $20-40 \mathrm{~cm})$ and treatments (specific composition and density).

All analyses were performed by SYSTAT 11 (SPSS Inc., Chicago, Illinois).

\section{Results}

\section{Living plants}

Taking root results are summarized in Fig. 2 and Tab. 2. In March, almost all plants were still alive ( $99 \%$ on average), with no differences among the densities and the specific compositions. In July, the average survival percentage was $93 \%$. No difference was found among densities and specific compositions at this sampling date. In October, the living plants were on average $34 \%$. Alive plants significantly $(\mathrm{p}<0.001)$ decreased from July to October, while no difference was observed between March and July. The decrease in living plants between July and October was affected by the specific composition $(p<0.001)$ : the highest mortality was observed in PL plots (from $95 \%$ of living plants to $11 \%$ ), while in JP and MIX plots survival decreased from $92 \%$ to $45 \%$. This reduction affected the average annual survival: PL was significantly poorer in plants $(69 \%, \mathrm{p}<0.001)$ than JP and MIX (79\% and $78 \%$, respectively). On average, D3 plots showed a slight tendency $(\mathrm{p}=0.1)$ to have more living plants (79\% compared to $74 \%$ in the D1 and $73 \%$ in D2 plots), but differences among the three densities were not significant. The three specific compositions did not have different survival rates at the different densities. Only at one occasion (October) there were more alive plants in the JP planted at D3 $(p<0.01)$ than in the PL plots at the same density.

In the MIX plots (Fig. 3, Tab. 3), Pistacia had on average lower $(\mathrm{p}<0.001)$ survival

Tab. 3 - Results of the ANOVA run for alive plants in the MIX plots for the three different species.

\begin{tabular}{lccc}
\hline \multicolumn{1}{c}{ Components } & df & F & P \\
\hline species & 2 & 13.45 & $<0.001$ \\
density & 2 & 2.02 & 0.14 \\
time & 2 & 194.01 & $<0.001$ \\
species*density & 4 & 0.27 & 0.90 \\
species*time & 4 & 2.67 & $<0.05$ \\
density*time & 4 & 0.47 & 0.76 \\
species*density*time & 8 & 0.65 & 0.73 \\
\hline
\end{tabular}




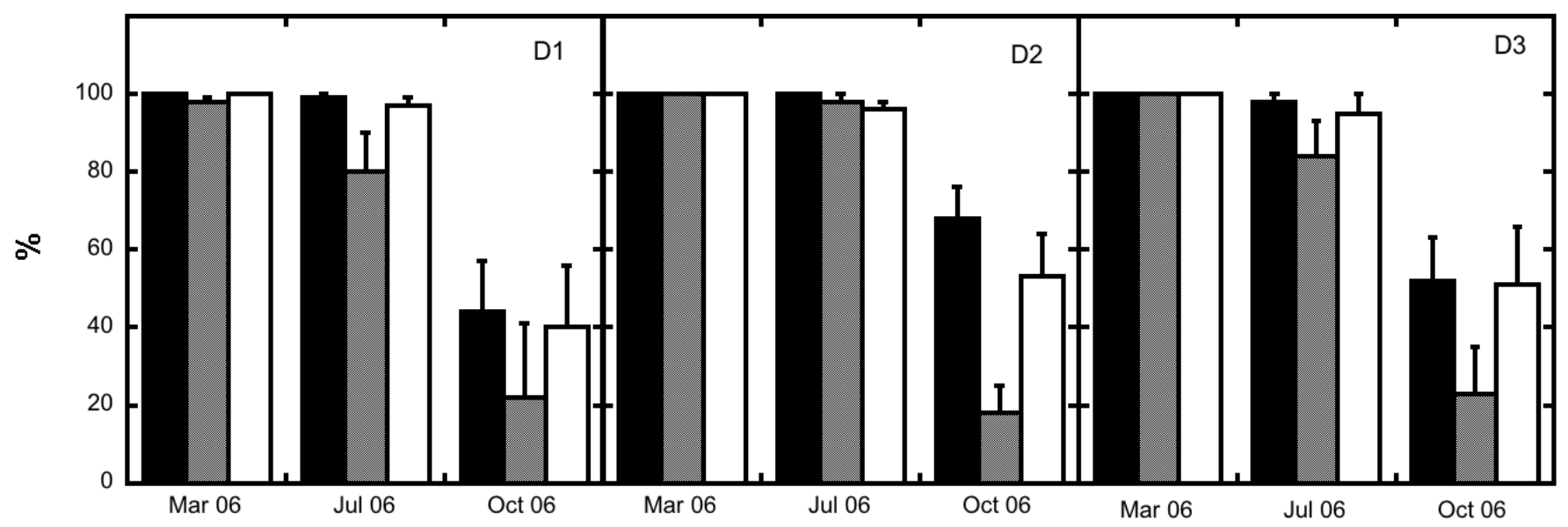

Fig. 3 - Living plants (\%) in the MIX plots at different densities and sampling time. Error bars indicate SE of the mean ( $\mathrm{n}=4)$. Black column $=J$. phoenicea; grey column $=P$. lentiscus; white column $=R$. officinalis. For details about the statistical differences among the treatments, see Tab. 3.

Tab. 4 - Estimated above-ground $(\mathrm{AB})$ and below-ground biomass $(\mathrm{BG}) \pm \mathrm{SE}$ in March 2006 (A) and October 2006 (B).

\begin{tabular}{|c|c|c|c|c|}
\hline Date & Species & Plots & $\begin{array}{l}\text { AG biomass } \\
\left(\mathrm{g} \mathrm{m}^{-2}\right)\end{array}$ & $\begin{array}{c}\text { BG biomass } \\
\quad\left(\mathrm{g} \mathrm{m}^{-2}\right)\end{array}$ \\
\hline \multirow[t]{9}{*}{ (A) March 2006} & \multirow[t]{3}{*}{ JP } & D1 & $2.43(0.67)$ & $1.17(0.29)$ \\
\hline & & D2 & $1.10(0.59)$ & $0.60(0.22)$ \\
\hline & & D3 & $3.36(1.28)$ & $1.62(0.56)$ \\
\hline & \multirow[t]{3}{*}{$\mathrm{PL}$} & D1 & $0.45(0.02)$ & $0.22(0.01)$ \\
\hline & & D2 & $0.71(0.09)$ & $0.35(0.05)$ \\
\hline & & D3 & $1.13(0.32)$ & $0.56(0.16)$ \\
\hline & \multirow[t]{3}{*}{ MIX } & D1 & $1.34(0.11)$ & $0.64(0.05)$ \\
\hline & & $\mathrm{D} 2$ & $1.49(0.21)$ & $0.79(0.08)$ \\
\hline & & D3 & $2.27(0.51)$ & $1.33(0.16)$ \\
\hline \multirow[t]{9}{*}{ (B) October 2006} & \multirow[t]{3}{*}{ JP } & D1 & $0.43(0.24)$ & $0.17(0.10)$ \\
\hline & & D2 & $0.23(0.09)$ & $0.10(0.03)$ \\
\hline & & D3 & $1.70(0.74)$ & $0.79(0.36)$ \\
\hline & \multirow[t]{3}{*}{ PL } & D1 & $0.00(0.00)$ & $0.00(0.00)$ \\
\hline & & D2 & $0.00(0.00)$ & $0.00(0.00)$ \\
\hline & & D3 & $0.01(0.01)$ & $0.00(0.00)$ \\
\hline & \multirow[t]{3}{*}{ MIX } & D1 & $0.33(0.18)$ & $0.15(0.08)$ \\
\hline & & $\mathrm{D} 2$ & $0.70(0.24)$ & $0.34(0.11)$ \\
\hline & & D3 & $0.89(0.39)$ & $0.47(0.21)$ \\
\hline
\end{tabular}

rates than Juniperus and Rosmarinus. In March, all plants belonging to all species and densities were recorded as alive. In July, percentage of living plants was on average $94 \%$, without any difference among species and densities. In October, the average survival rate was $41 \%$, but significant lower rates $(\mathrm{p}<0.001)$ were recorded for Pistacia plants ( $21 \%$, compared to $55 \%$ and $48 \%$ respectively for Juniperus and Rosmarinus), independently on the density. Survival rate changed over time $(p<0.001)$, with lower average values in October, independently on species and density.

\section{Plant biomass}

Total biomass in March 2006 ranged

0.7 and $5.0 \mathrm{~g} \mathrm{~m}^{-2}$ with an aver value of $2.3 \mathrm{~g} \mathrm{~m}^{-2}$ (Tab. 4). Aboveground
(AG) biomass was on average $1.5 \mathrm{~g} \mathrm{~m}^{-2}$, ranging between 0.4 and $3.4 \mathrm{~g} \mathrm{~m}^{-2}$. On average, PL plots had less AG biomass $\left(0.8 \mathrm{~g} \mathrm{~m}^{-2}\right.$; $\mathrm{p}<0.01$, after post-hoc test) than JP plots (2.3 $\mathrm{g} \mathrm{m}^{-2}$ ), independently on density, but not than the MIX plots $\left(1.7 \mathrm{~g} \mathrm{~m}^{-2}\right)$. MIX and JP AG biomasses were not different between each other. On average, D3 plots had a tendency ( $\mathrm{p}=0.061$, after post-hoc test) to have more AG biomass $\left(2.3 \mathrm{~g} \mathrm{~m}^{-2}\right)$ than the other two densities (1.4 and $1.1 \mathrm{~g} \mathrm{~m}^{-2}$, respectively).

Mean belowground (BG) biomass in March was $0.8 \mathrm{~g} \mathrm{~m}^{-2}$, varying between $0.2 \mathrm{~g}$ $\mathrm{m}^{-2}$ and $1.6 \mathrm{~g} \mathrm{~m}^{-2}$. Mean BG biomass in PL plots was lower $\left(\mathrm{p}<0.01 ; 0.4 \mathrm{~g} \mathrm{~m}^{-2}\right)$ than in JP $\left(1.1 \mathrm{~g} \mathrm{~m}^{-2}\right)$ and MIX $\left(0.9 \mathrm{~g} \mathrm{~m}^{-2}\right)$ plots. On average, in $\mathrm{D} 3$ plots there was a higher $(p<0.05)$ amount of BG biomass compared to both the other two densities.

Biomass in October was on average $80 \%$ of that of March $(\mathrm{p}<0.001)$, having values in the range of 0 to $2.5 \mathrm{~g} \mathrm{~m}^{-2}$. PL plots had significant lower AG biomass (about zero; $\mathrm{p}<0.05)$ than in the other two specific compositions ( 0.8 and 0.6 respectively for JP and MIX), independent of density. D3 plots had on average higher AG biomass $\left(0.9 \mathrm{~g} \mathrm{~m}^{-2}\right.$; $\mathrm{p}<0.05)$ compared to D1 $\left(0.3 \mathrm{~g} \mathrm{~m}^{-2}\right)$ but not

Tab. 5 - ANOVA results of biomass data, calculated in February and March 2006.

\begin{tabular}{llcccccc}
\hline \multirow{2}{*}{ Biomass } & \multicolumn{3}{c}{ March } & \multicolumn{3}{c}{ October } \\
\cline { 3 - 8 } & & df & F & P & df & F & P \\
\hline Above-ground & specific composition & 2 & 5.75 & $<0.01$ & 2 & 5.39 & $<0.05$ \\
biomass & density & 2 & 3.26 & 0.054 & 2 & 3.57 & $<0.05$ \\
& specific composition * density & 4 & 0.95 & 0.45 & 4 & 1.97 & 0.13 \\
\hline Below-ground & specific composition & 2 & 8.07 & $<0.01$ & 2 & 0.46 & $<0.05$ \\
biomass & density & 2 & 5.36 & $<0.05$ & 2 & 0.34 & $<0.05$ \\
& specific composition * density & 4 & 1.21 & 0.33 & 4 & 0.17 & 0.15 \\
\hline Total biomass & specific composition & 2 & 6.38 & $<0.01$ & 2 & 5.28 & $<0.05$ \\
& density & 2 & 4.03 & $<0.05$ & 2 & 3.64 & $<0.05$ \\
& specific composition * density & 4 & 0.97 & 0.44 & 4 & 1.92 & 0.14 \\
\hline
\end{tabular}



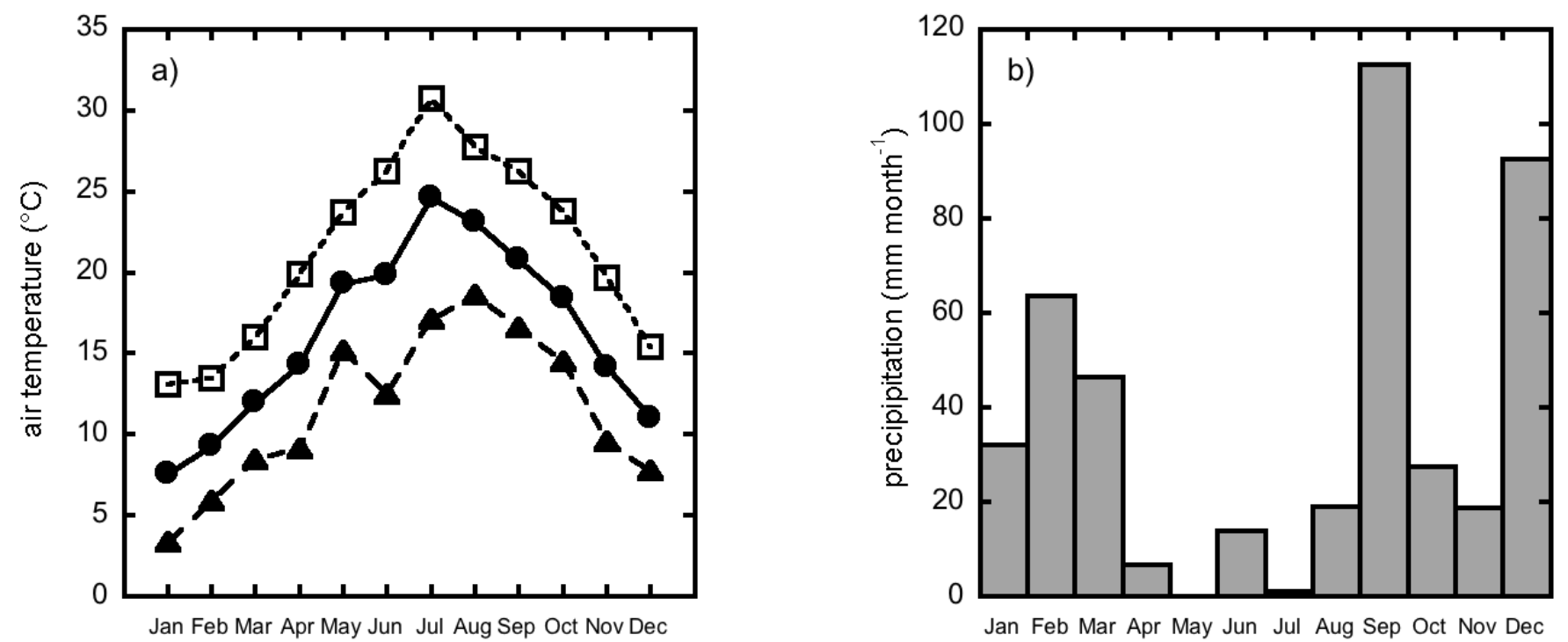

Fig. 4 - Monthly values of air temperature and precipitation during the years 2006: a) mean temperature (full circle with continuous line), mean maximum temperature (open square with short dashed line) and mean minimum temperature (closed triangles with long-dashed line); b) monthly precipitation. The climate station is located $1 \mathrm{~km}$ far from the plantation.

Tab. 6 - Soil nutrient $( \pm$ SE; $n=3)$ just before the plantation at two depths. Different lowercase letters indicate significant differences $(p<0.05)$ between the two depths inside each parameter.

\begin{tabular}{cccc}
\hline $\begin{array}{c}\text { Layer } \\
(\mathbf{c m})\end{array}$ & $\mathbf{N \%}$ & $\mathbf{C} \%$ & $\mathbf{C} / \mathbf{N}$ \\
\hline $0-20$ & 0.15 & 1.71 & 11.68 \\
& $(0.01) \mathrm{a}$ & $(0.07) \mathrm{a}$ & $(0.16) \mathrm{a}$ \\
$20-40$ & 0.14 & 1.56 & 11.33 \\
& $(0.01) \mathrm{a}$ & $(0.07) \mathrm{a}$ & $(0.16) \mathrm{a}$ \\
\hline
\end{tabular}

Tab. 7 - Average values of global radiation and air temperaturte and total precipitation during the year 2006. Concerning air temperature, the three values displayed are annual averages of the mean, minimum and maximum temperatures, respectively.

\begin{tabular}{lcc}
\hline Global Radiation & $\mathrm{MJ} \mathrm{m}^{-2} \mathrm{~d}^{-1}$ & 15.0 \\
\hline Air temperature & ${ }^{\circ} \mathrm{C}$ & 15.5 \\
& & 11.1 \\
& & 20.7 \\
\hline Total precipitation & $\mathrm{mm}$ & 434 \\
\hline
\end{tabular}

compared to D2 $\left(0.3 \mathrm{~g} \mathrm{~m}^{-2}\right)$.

BG biomass in October was on average 0.2 $\mathrm{g} \mathrm{m}^{-2}$, with a lower amount in PL plots $(\mathrm{p}<0.05)$. BG biomass in D3 plots $\left(0.4 \mathrm{~g} \mathrm{~m}^{-2}\right)$ was significantly higher than what observed in D1 $\left(0.1 \mathrm{~g} \mathrm{~m}^{-2} ; \mathrm{p}<0.05\right)$, but not in D2. D1 and D2 BG biomass were not different.

Concerning Juniperus phoenicea, its R/S in March was in the order of 0.9-0.6 in the monospecific and mixed plots, respectively, with no differences among the densities.
Similarly, no effect of specific composition and density was observed in October, with values in the range of 0.5-0.6. Time did not affected R/S at all specific composition and densities.

\section{Soil carbon and nitrogen}

The soil N content was $0.11-0.17 \%$; the soil $\mathrm{C}$ content varied between $1.2 \%$ and $2 \%$ (Tab. 2). No significant differences were found between the TOC content at the two depths and among densities and specific compositions, as also found for the TN values (Tab. 6). The $\mathrm{C} / \mathrm{N}$ ratio was on average 11.5, not different at the two depths and among densities and specific compositions (Tab. 6).

\section{Discussion}

Seedling survival after eight months ranged between $40-50 \%$. These values are similar to those reported in other studies concerning plantations in Mediterranean region with different species (Clemente et al. 2004, Rey Benayas \& Camacho-Cruz 2004, Navarro Cerrillo et al. 2005). Only P. lentiscus showed a very high mortality rates, similar to those found by Garcia-Fayos \& Verdu (1998) and Maestre et al. (2006).

The high mortality rate is normally associated to summer aridity (Castro et al. 2004a, Castro et al. 2004b, Maestre et al. 2006). In this study the late planting time (February), added to an early aridity in April 2006, when it rained only $7 \mathrm{~mm}$ (Fig. 4, Tab. 7), might have reduced root development before the occurrence of summer drought, affecting seedling survival (Lloret et al. 1999, Padilla \& Pugnaire 2007).

The different mortality observed among the three planted species could be related to the plant functional types (PFT) they belong. $P$. lentiscus is a hygrophytic sclerophyll shrub, while $R$. officinalis and $J$. phoenicea are both xerophytic with a semi-deciduous and a sclerophyll habit, respectively (Ain-Lhout et al. 2004). P. lentiscus has an evergreen broad-leaf habit compared to the other two species: this characteristic makes it weaker in front of summer drought, when water table is not achievable, due to a lower control of water balance. Similarly, Gratani \& Varone (2004) asserted that during drought $R$. officinalis has a higher decrease of photosynthesis and stomatal conductance followed by a higher recovery capacity than $P$. lentiscus. In the future, physiological measurements will be necessary to make clear this issue.

Plants compete for water and nutrient resources, and this competition may result in a negative effect on growth and on seedlings survival (Löf et al. 2006, Perez-Devesa et al. 2008). Our results showed that higher densities had more biomass and had a tendency towards higher survival rates. This positive effect of density on biomass, concomitant with the unchanged R/S (at least for Juniper$u s$ ) can be interpreted as a lack of interaction and competition among plants for water and nutrient resources, likely due to the small dimension of plants. The lack of difference in mortality rates of $J$. phoenicea and P. lentiscus in the mixed plots compared to those of the same species in the monospecific plots support the same conclusion.

Frequently in the past, afforestation practices were done in areas where crops were cultivated, where seed bank of forest species were not available, making difficult the suc- 
cession and evolution of a stable ecosystem Our intervention, on the contrary, was set up near a pine forest with an understory of $P$. lentiscus, Phillirea spp. and other maquis species. As reported by Bonet (2004) and Pareliussen et al. (2006), reforestation and restoration are likely to be more successful if efforts are focused on expanding the existing fragments of natural remnant vegetation supplying seed bank, rather than on establishing new fragments in openings.

Because of land abandonment, shrubs in the future will encroach (Goodale \& Davidson 2002, Jackson et al. 2002), whereas, because of climate change, Mediterranean forests will likely face considerable threats (Resco de Dios et al. 2007). In a recent work, Harris et al. (2006) wondered how appropriate is to restore historical ecosystem types when facing rapidly changes of biophysical conditions. According to the same authors, recovery of threatened species and ecosystems will be more difficult to achieve in the future. Therefore, we used plants that can cope with the altered climate conditions (Hughes 2003, Ogaya et al. 2003, Bartolomè et al. 2005). Experimental evidence showed that once established, those species have the ability to recover rapidly after sever drough effects (Hastings et al. 2005, Luo et al. 2007, Pereira et al. 2007), and to sustain elevated Net Ecosystem Exchange (NEE), comparable to forests, as a consequence of the relative low $\mathrm{C}$ loss via respiration.

According to the FAO Forest Resource Assessment (FAO 2005), 30 million ha are covered by "other wooded lands", including shrublands, in the Mediterranean basin. As far as Italy, the last National Inventory of Forest and Carbon INFC dated 2005 (http:// www.sian.it/inventarioforestale/jsp/home.js) reported that shrublands cover about 991,000 ha, that include about 690,100 ha of Mediterranean maquis and shrubs, while the remaining surface is covered by shrubs of subalpine and temperate climate. Considering their vast diffusion, efforts should be done to evaluate the potential of these ecosystems in sequestering $\mathrm{C}$ in order to achieve the Kyoto Protocol commitments. In this study, we measured plant biomass and soil $\mathrm{C}$, representing the first step of the inventory along the time series. Therefore, only previsions can be merely assumed, given the need of long term monitoring, at least 5-10 years (Post et al. 2001, Sudha et al. 2007). Some authors reported a woody biomass increment by $0.25-0.60 \mathrm{t} \mathrm{ha}^{-1} \mathrm{yr}^{-1}$ (Peressotti et al. 1999 , De Dato et al. 2008) for similar vegetation in Mediterranean climate.

In a Mediterranean environment, La Mantia et al. (2007) showed a linear increase from 13 to $85 \mathrm{t} \mathrm{C} \mathrm{ha}^{-1}$ of soil organic $\mathrm{C}$ along a soil chronosequence of $0-30$ years after land abandonment. In an area close to our experimental plantation, covered by a 30 - year old maquis, soil $\mathrm{C}$ is about $87 \mathrm{t} \mathrm{C} \mathrm{ha}^{-1}$, which is in agreement with the data given by La Mantia et al. (2007). Presently in our plantation, assuming a reasonable soil bulk density of about 1.1-1.2 $\mathrm{g} \mathrm{cm}^{-3}$ (Caravaca et al. 2003b, Celik 2005), soil $\mathrm{C}$ is about 0.7$0.8 \mathrm{t} \mathrm{ha}^{-1}$. Based on our soil $\mathrm{CO}_{2}$ emissions measurements (data not shown, but a likely estimation would be $7 \mathrm{t} \mathrm{C} \mathrm{ha}^{-1} \mathrm{yr}^{-1}$ ) and on the low biomass accumulation, the plantation will be a net $\mathrm{C}$ source in the first stages. This is in agreement with Paul et al. (2002), who showed that soil $\mathrm{C}$ generally decreased in the first years after plantation, as an effect of the initial low $\mathrm{C}$ input from litter, while contemporarily the old $\mathrm{C}$ of the preceding agricultural phase continued to decompose, until this effect disappeared in the long term $(>30$ years), when soil $\mathrm{C}$ became higher than in the preceding agricultural soil.

\section{Conclusions}

Forest policy has changed in Italy and Europe during the last decades. The main goals that characterized forest plantations until last decades were to give job to people and to involuntary develop non-regenerating forests, especially in case of lack of management, as occurred for the Italian forests. The likely positive long-term impacts of afforestation activities in arid and semi-arid environments by shrubs species can make wonder if these types of plantations might be a valid alternative to classic revegetation activities when the goal of increasing biological diversity, reducing soil erosion and creating C sink are pursued (Pausas et al. 2004). Higher densities and mixed specific composition seemed to better perform, allowing establishment of species with a strong pioneer behaviour and aridity resistant characteristics. Data collection on initial conditions and recurrent monitorings will be effective for evaluating the potential of $\mathrm{C}$ sequestration in the long-term by afforestation in semi-arid Mediterranean areas.

\section{Acknowledgments}

The research was funded by the Ministry of Environment (Ministero dell'Ambiente e della Tutela dell'Ambiente e del Mare) under the frame of a bilateral collaborative international programme (2006). We also would like to acknowledge the Regional Forest Service in the persons of Dr. Nudda, Dr. Caporali, Dr. D'Angelo, for the support on this research. Finally, we acknowledge Mr. Bianchi and all the workers of the Regional Forest Service for the support in the practical works and for logistics. We are particularly thankful to Dr. Alberto Masci and Dr. Abou Jaoudé Renée for their comments and suggestions.

\section{References}

Ain-Lhout F, Barradas MCD, Zunzunegui M, Castro J, Zamora R, Hódar JA, Gómez JM
Rodríguez H, Novo FG, Vargas MA (2004). Seasonal differences in photochemical efficiency and chlorophyll and carotenoid contents in six mediterranean shrub species under field conditions. Photosynthetica 42: 399-407. - doi: 10.1023/B:PHOT.0000046159.96228.49

Bartolomè J, Plaixats J, Fanlo R, Boada M (2005). Conservation of isolated Atlantic heathlands in the Mediterranean region: effects of land-use changes in the Montseny biosphere reserve (Spain). Biological Conservation 122: 81-88. doi: 10.1016/j.biocon.2004.05.024

Begni G, Darras S, Hoepffner M, Pesin E, Tourre Y (2001). The present status of knowledge on Global Climatic Change; its regional aspects and impacts in the Mediterranean Region. A scientific and strategic report to Blue Plan. Medias France Groupement pour le developpement de la recherche sur l'environnement global notamment dans le bassin mediterraneen et l'Afrique subtropicale. December $7^{\text {th }} 2001$, Toulouse (France). Bellot J, Maestre FT, Chirino E, Hernández N, de Urbina JO (2004). Afforestation with Pinus halepensis reduces native shrub performance in a Mediterranean semiarid area. Acta Oecologica 25: 7-15. - doi: 10.1016/j.actao.2003.10.001

Bianchi L, Calamini G, Gregori E, Paci M, Tani A, Zorn G (2005). Valutazione degli effetti del rimboschimento in zone aride della Sardegna. Italia Forestale e Montana 1: 47-66.

Biondi E, Filigheddu R, Farris E (2001). Il paesaggio vegetale della Nurra (Sardegna nord-occidentale). Fitosociologia 38: 3-105.

Bonet A (2004). Secondary succession of semiarid Mediterranean old-fields in south-eastern Spain: insights for conservation and restoration of degraded lands. Journal of Arid Environments 56: 213-233. - doi: 10.1016/S01401963(03)00048-X

Caravaca F, Alguacil MM, Figueroa D, Barea JM, Roldán A (2003a). Re-establishment of Retama sphaerocarpa as a target species for reclamation of soil physical and biological properties in a semi-arid Mediterranean area. Forest Ecology and Management 182: 49-58. - doi 10.1016/S0378-1127(03)00067-7

Caravaca F, Figueroa D, Alguacil MM, Roldán A (2003b). Application of composted urban residue enhanced the performance of afforested shrub species in a degraded semiarid land. Bioresource Technology 90: 65-70. - doi: 10.1016/S09608524(03)00087-7

Caravaca F, Figueroa D, Azcón-Aguilar C, Barea JM, Roldán A (2003c). Medium-term effects of mycorrhizal inoculation and composted municipal waste addition on the establishment of two Mediterranean shrub species under semiarid field conditions. Agriculture, Ecosystems and Environment 97: 95-105. - doi: 10.1016/S01678809(03)00126-9

Castro J, Zamora R, Hodar JA, Gomez JM (2002). Use of shrubs as nurse plant: a new technique for restoration in Mediterranean mountain. Restoration Ecology 10: 297-305. - doi: 10.1046/j.1526100X.2002.01022.X 
(2004a). Seedling establishment of a boreal tree species (Pinus sylvestris) at its southernmost distribution limit: consequences of being in a marginal Mediterranean habitat. Journal of Ecology 92: 266-277. - doi: 10.1111/j.0022-0477.2004 00870.x

Castro J, Zamora R, Hódar JA, Gómez JM, Gómez-Aparicio L (2004b). Benefits of using shrubs as nurse plants for reforestation in Mediterranean mountains: a 4-year study. Restoration Ecology 12: 352-358. - doi: 10.1111/j.10612971.2004.0316.x

Celik I (2005). Land-use effects on organic matter and physical properties of soil in a southern Mediterranean highland of Turkey. Soil and Tillage Research 83: 270-277. - doi: 10.1016/j.still. 2004.08.001

Clemente AS, Werner C, Máguas C, Cabral MS, Martins-Loução MA, Correia O (2004). Restoration of a limestone quarry: effect of soil amendments on the establishment of native Mediterranean Sclerophyllous Shrubs. Restoration Ecology 12: 20-28. - doi: 10.1111/j.10612971.2004.00256.x

Corona P (2005). Desertificazione, siccità, foreste e ricerca. Forest@ 2: 256-257. [online] URL: http://www.sisef.it/forest@/show.php?id=299

Costantini EAC, Bocci M, L'Abate G, Fais A, Leoni G, Loy G, Magini S, Napoli R, Nino P, Paolanti M, Salvestrini L, Tascone F, Urbano F (2004). Mapping the state and risk of desertification in Italy by means of remote sensing, soil GIS and the EPIC model. Methodology Validation on the Island of Sardinia, Italy. [online] URL: http://www.soilmaps.it/ita/progetti2_1. html

De Dato GD (2004). Effetti dei cambiamenti climatici sulla vegetazione arbustiva mediterranea: risultati della manipolazione ambientale nell'area sperimentale di Porto Conte (SS). Università degli Studi della Tuscia, Viterbo (Italy).

De Dato GD, Pellizzaro G, Cesaraccio C, Sirca C, De Angelis P, Duce P, Spano D, Scarascia Mugnozza G (2008). Effects of warmer and drier climate conditions on plant composition and biomass production in a Mediterranean shrubland community. iForest 1: 39-48. - doi 10.3832/ifor0418-0010039

Eliason SA, Allen EB (1997). Exotic grass competition in suppressing native shrubland re-establishment. Restoration Ecology 245-255. - doi: 10.1046/j.1526-100X.1997.09729.x

Estaún V, Savé R, Biel C (1997). AM inoculation as a biological tool to improve plant revegetation of a disturbed soil with Rosmarinus officinalis under semi-arid conditions. Applied Soil Ecology 6: 223-229. - doi: 10.1016/S09291393(97)00014-0

FAO (2005). Global Forest Resources Assessment 2005. Progress towards sustainable forest management. FAO, Rome (Italy).

Garcia-Fayos P, Verdu M (1998). Soil seed bank, factors controlling germination and establishment of a Mediterranean shrub: Pistacia lentiscus L. Acta Oecologica 19: 357-366. - doi: 10.1016/S1146-609X(98)80040-4
Garcia C, Hernandez T, Roldan A, Martin A (2002). Effect of plant cover decline on chemical and microbiological parameters under Mediterranean climate. Soil Biology and Biochemistry 5: 635-642. - doi: 10.1016/S0038-0717(01)00225-5 Ginsberg P (2002). Planning and management of the afforestation process in Northern Israel. New Forests 24: 27-38. - doi: 10.1023/A:1020523 923551

Goberna M, Sánchez J, Pascual JA, García C (2007). Pinus halepensis Mill. plantations did not restore organic carbon, microbial biomass and activity levels in a semi-arid Mediterranean soil. Applied Soil Ecology 36: 107-115. - doi: 10.1016/j.apsoil.2006.12.003

Goodale CL, Davidson EA (2002). Uncertain sinks in the shrubs. Nature 418: 593-594. - doi: $10.1038 / 418593 a$

Gratani L, Varone L (2004). Adaptive photosynthetic strategies of the Mediterranean maquis species according to their origin. Photosynthetica 42: 481-486. - doi: 10.1007/S11099-005-0012-3

Green JJ, Baddeley JA, Cortina J, Watson CA (2005). Root development in the Mediterranean shrub Pistacia lentiscus as affected by nursery treatments. Journal of Arid Environments 61: 112. - doi: 10.1016/j.jaridenv.2004.09.001

Harris JA, Hobbs RJ, Higgs E, Aronson J (2006). Ecological restoration and global climate change. Restoration Ecology 14: 170-176. - doi: 10.1111/ j.1526-100X.2006.00136.x

Hastings SJ, Oechel WC, Muhlia-Melo A (2005). Diurnal, seasonal and annual variation in the net ecosystem $\mathrm{CO}_{2}$ exchange of a desert shrub community (Sarcocaulescent) in Baja California, Mexico. Global Change Biology 11: 927-939. doi: 10.1111/j.1365-2486.2005.00951.x

Hughes L (2003). Climate change and Australia: Trends, projections and impacts. Austral Ecology 28: 423-443. - doi: 10.1046/j.1442-9993.2003. 01300.x

Jackson RB, Banner JL, Jobbagy EG, Pockman WT, Wall DH (2002). Ecosystem carbon loss with woody plant invasion of grassland. Nature 418: 623-626. - doi: 10.1038/nature00910

Kassas M (1999). Rescuing drylands: a project for the world. Futures 31: 949-958. - doi: 10.1016/S0016-3287(99)00054-3

La Mantia T, Oddo G, Rühl J, Furnari G, Scalenghe R (2007). Variazione degli stock di carbonio del suolo in seguito ai processi di abbandono dei coltivi: il caso studio dell'isola di Pantelleria (TP). Forest@ 4: 102-109. - doi: 10.3832/ efor0433-0040102

Lal R (2001). Potential of desertification control to sequester carbon and mitigate the greenhouse effect. Climate Change 51: 35-72. - doi: 10.1023/A:1017529816140

Lloret F, Casanovas C, Peñuelas J (1999). Seedling survival of Mediterranean shrubland species in relation to root:shoot ratio, seed size and water and nitrogen use. Functional Ecology 13: 210216. - doi: 10.1046/j.1365-2435.1999.00309.x Löf M, Rydberg D, Bolte A (2006). Mounding site preparation for forest restoration: survival and short term growth response in Quercus robur L. seedlings. Forest Ecology and Management 232: 19-25. - doi: 10.1016/j.foreco.2006.05.003

López-Bermúdez F, Romero-Díaz A, MartínezFernandez J, Martínez-Fernandez J (1998). Vegetation and soil erosion under a semi-arid Mediterranean climate: a case study from Murcia (Spain). Geomorphology 24: 51-58. - doi: 10.1016/S0169-555X(97)00100-1

Luo H, Oechel WC, Hastings SJ, Zulueta R, Qian Y, Kwon H (2007). Mature semiarid chaparral ecosystems can be a significant sink for atmospheric carbon dioxide. Global Change Biology 13: 386-396. - doi: 10.1111/j.13652486.2006.01299.x

Maestre FT, Bautista S, Cortina J (2003). Positive, negative, and net effects in grass-shrub interactions in Mediterranean semiarid grassland. Ecology 84: 3186-3197. - doi: 10.1890/02-0635

Maestre FT, Cortina J (2004). Are Pinus halepensis plantations useful as a restoration tool in semiarid Mediterranean areas? Forest Ecology and Management 198: 303-317. - doi: 10.1016/j.foreco.2004.05.040

Maestre FT, Cortina J, Bautista S (2004). Mechanism underlying the interaction between Pinus halepensis and the native late-successional shrub Pistacia lentiscus in a semi-arid plantation. Ecography 27: 776-786. - doi: 10.1111/j.09067590.2004.03990.x

Maestre FT, Cortina J, Bautista S, Bellot J (2003) Does Pinus halepensis facilitate the establishment of shrubs in Mediterranean semi-arid afforestations? Forest Ecology and Management 176: 147-160.

Maestre FT, Cortina J, Vallejo R (2006). Are ecosystem composition, structure, and functional status related to restoration success? A test from semiarid Mediterranean steppes. Restoration Ecology 14: 258-266. - doi: 10.1111/j.1526100X.2006.00128.x

Martínez ML (2003). Facilitation of seedling establishment by an endemic shrub in tropical coastal sand dunes. Plant Ecology 168: 333-345. - doi: 10.1023/A:1024406707115

Navarro Cerrillo RM, Fragueiro B, Ceaceros C, del Campo A, de Prado R (2005). Establishment of Quercus ilex L. subsp. ballota [Desf.] Samp. using different weed control strategies in southern Spain. Ecological Engineering 25: 332-342. - doi: 10.1016/j.ecoleng.2005.06.002

Ogaya R, Peñuelas J, Martinez-Vilalta J, Mangiron M (2003). Effect of drought on diameter increment of Quercus ilex, Phillyrea latifolia, and Arbutus unedo in a holm oak forest of NE Spain. Forest Ecology and Management 180: 175-184. - doi: 10.1016/S0378-1127(02)00598-4 Olukoye GA, Wamicha WN, Kinyamario JI (2003). Assessment of the performance of exotic and indigenous tree and shrub species for rehabilitating saline soils of Northern Kenya. African Journal of Ecology 41: 164-170. - doi: 10.1046/j.1365-2028.2003.00430.x

Padilla FM, Pugnaire FI (2006). The role of nurse plants in the restoration of degraded environments. Frontiers in Ecology and the Environment 4: 196-202. - doi: 10.1890/1540-9295(2006)004 
[0196:TRONPI]2.0.CO;2

Padilla FM, Pugnaire FI (2007). Rooting depth and soil moisture control Mediterranean woody seedling survival during drought. Functional Ecology 21: 489-495. - doi: 10.1111/j.13652435.2007.01267.x

Pareliussen I, Olsson EGA, Armbruster WS (2006). Factors limiting the survival of native tree seedlings used in conservation efforts at the edges of forest fragments in upland Madagascar. Restoration Ecology 14: 196-203. - doi: 10.1111/ j.1526-100X.2006.00121.x

Pariente S (2002). Spatial patterns of soil moisture as affected by shrubs, in different climatic conditions. Environmental Monitoring and Assessment 733: 237-251. - doi: 10.1023/A:1013119405441

Pascual JA, Garcia C, Hernandez T, Moreno JL, Ros M (2000). Soil microbial activity as a biomarker of degradation and remediation processes. Soil Biology and Biochemistry 32: 1877 1883. - doi: 10.1016/S0038-0717(00)00161-9

Paul KI, Polglase PJ, Nyakuengama JG, Khanna PK (2002). Change in soil carbon following afforestation. Forest Ecology and Management 168: 241-257. - doi: 10.1016/S03781127(01)00740-X

Pausas JG, Bladé C, Valdecantos A, Seva JP, Fuentes D, Alloza JA, Vilagrosa A, Bautista S, Cortina J, Vallejo R (2004). Pines and oaks in the restoration of Mediterranean landscapes of Spain: new perspectives for an old practice - a review. Plant Ecology 171: 209-220. - doi: 10.1023/B:VEGE.0000029381.63336.20

Pereira JS, Mateus JA, Aires LM, Pita G, Pio C,
David JS, Andrade V, Banza J, David TS, Paço TA, Rodrigues A (2007). Net ecosystem carbon exchange in three contrasting Mediterranean ecosystems - the effect of drought. Biogeosciences 4: 791-802.

Peressotti A, Asunis C, Cesaraccio C (1999). Stima indiretta della biomassa e della copertura vegetale di un ecosistema mediterraneo a macchia: il caso della riserva naturale integrale Arca di Noè. In: "Monitoraggio di un ecosistema a macchia mediterranea: misure ecofisiologiche e micrometeorologiche". CNR Istituto Nazionale per l'Analisi e la Protezione degli Agroecosistemi, Collana tecnico - scientifica INAPA, Quaderno n. 6.

Perez-Devesa M, Cortina J, Vilagrosa A, Vallejo R (2008). Shrubland management to promote Quercus suber L. establishment. Forest Ecology and Management 255: 374-382. - doi: 10.1016/j.foreco.2007.09.074

Pietracaprina A (1989). La Nurra, sintesi monografica. Gallizzi Edizioni, Sassari (Italy).

Post WM, Izaurralde RC, Mann LK, Bliss N (2001). Monitoring and verifying changes of organic carbon in soil. Climatic Change 51: 73-99. - doi: 10.1023/A:1017514802028

Resco de Dios V, Fischer C, Colinas C (2007). Climate change effects on Mediterranean forests and preventive measures. New Forests 33: 29-40. - doi: 10.1007/s11056-006-9011-x

Rey Benayas JM, Camacho-Cruz A (2004). Performance of Quercus ilex saplings planted in abandoned Mediterranean cropland after longterm interruption of their management. Forest
Ecology and Management 194: 223-233. - doi: 10.1016/j.foreco.2004.02.035

Rey Benayas JM, Navarro J, Espigares T, Nicolau JM, Zavala MA (2005). Effects of artificial shading and weed mowing in reforestation of Mediterranean abandoned cropland with contrasting Quercus species. Forest Ecology and Management 212: 302-314. - doi: 10.1016/j.foreco.2005. 03.032

Rey Benayas JM, López-Pintor A, García C, de la Cámara N, Strasser R, Sal AG (2002). Early establishment of planted Retama sphaerocarpa seedlings under different levels of light, water and weed competition. Plant Ecology 159: 201209. - doi: 10.1023/A:1015562623751

Sarah P, Rodeh Y (2004). Soil structure variations under manipulations of water and vegetation. Journal of Arid Environments 58: 43-57. - doi: 10.1016/S0140-1963(03)00126-5

Sudha P, Ramprasad V, Nagendra M, Kulkarni H, Ravindranath N (2007). Development of an agroforestry carbon sequestration project in Khammam district, India. Mitigation and Adaptation Strategies for Global Change 12: 11311152. - doi: 10.1007/s11027-006-9067-0

USDA (1993). Soil Survey Manual. Washington, DC, USA.

Valsecchi F (1976). Sui principali aspetti della vegetazione costiera della Nurra Nord-occidentale (Sardegna settentrionale). Giornale Botanico Italiano 110: 21-63.

Yaalon DH (1997). Soils in the Mediterranean region: what makes them different? Catena 283-4: 157-169. - doi: 10.1016/S0341-8162(96)00035-5 